\title{
Kajian Hukum Penghentian Terapi Bantuan Hidup (Withdrawing Of Life Support) Dalam Perawatan Paliatif
}

\author{
Agung Sediatmojo ${ }^{1}$, Sutarno $^{2}$, Ninis Nugraheni $^{3}$ \\ ${ }^{1}$ Fakultas Hukum, Universitas Hang Tuah, Jl. Arif Rahman Hakim No.150, Surabaya, 60111 \\ E-mail: agung.sediatm@student.hangtuah.ac.id \\ ${ }^{2}$ Fakultas Hukum, Universitas Hang Tuah, Jl. Arif Rahman Hakim No.150, Surabaya, 60111 \\ E-mail: - \\ ${ }^{3}$ Fakultas Hukum, Universitas Hang Tuah, Jl. Arif Rahman Hakim No.150, Surabaya, 60111 \\ E-mail: -
}

\begin{abstract}
Withdrawing of life support was chosen as a preventive measure for the suffering of a person with an incurable disease. This action was taken because there is no other way that can help a person to escape the terrible suffering at the end of his life. Withdrawing of life support should observe the principle of Palliative Care, it does not aim to accelerate or prolo ng the patient's life. This research analyzes the legal norms of Withdrawing of life support using a statute approach, a conceptual approach and a comparative approach. The aim is to examine whether this action can be classified as an illegal act and what $i$ s the legal responsibility for the doctor who did it. Withdrawing of life support as Palliative Care is still continuing the normal treatment as a form of maintaining the quality of life for patients, while extraordinary treatments that are felt to be useless and futile. Determining what is ordinary or extraordinary is very important so that doctors and nurses can be sure that their professional actions do not violate ethics or law. Doctors as perpetrators of withdrawing of life support in Indonesia cannot be classifie d as a criminal crime against life. In outward acts (actus reus), these actions can result in the loss of a person's life. But the mental attitude (mens rea) to Withdrawing of Life Support is very different from murder. Civil liability arises when there is a violation of the rights of others, a violation of the perpetrator's legal obligations, violates decency and morality and violates the behavior of a good citizen. Good citizen behavior for a doctor refers to professional standards, standard operating procedures, medical code of ethics and the behavior of other colleagues.
\end{abstract}

Keywords —: legal aspect; responsibility; withdrawing of life support; palliative care.

\section{PENDAHULUAN}

Teknologi menjadi kebutuhan mutlak yang tak dapat dihindari khususnya teknologi kesehatan yang mempunyai tingkat penggunaan tinggi, beresiko tinggi, berbiaya tinggi, memiliki variasi yang besar, mempunyai urgensi yang mendesak dan tidak bertentangan dengan aspek sosial budaya. Namun tidak selamanya teknologi mampu menjawab permasalahan kesehatan. Ketika pasien dalam kondisi terminal dan segala upaya medis dirasakan sia sia, tindakan Penghentian Terapi Bantuan Hidup menjadi pilihan dalam Perawatan Paliatif.

Dari sudut pandang pasien, karena merasakan penderitaan yang tidak tertahankan lagi akibat penyakit yang sudah tidak mungkin disembuhkan, bukan mustahil pasien minta agar hidupnya diakhiri saja. Pasien hanya memperpanjang hidup dengan kondisi tidak bermartabat dan penuh penderitaan. Pasien diberikan obat penenang dan penghilang nyeri dalam dosis besar untuk membuat pasien terlihat nyaman namun disisi lain kita tidak tau apakah pasien tersebut sebenarnya merasakan kenyamanan itu atau tidak. Keputusan untuk melakukan Penghentian Terapi Bantuan Hidup sering menjadi jalan tengah dengan menyerahkan tubuh pasien menjalani proses alamiah. ${ }^{1}$ Dokter menjadi pihak yang seringkali dihadapkan pada pilihan yang sulit. Di satu sisi penghentian terapi bantuan hidup menjadi pilihan dan kehendak pihak pasien untuk mengakhiri penderitaan, di sisi lain dokter wajib memberikan bantuan hidup dasar pada pasien yang mengalami kondisi sakit kritis karena mempertimbangkan keselamatan hidup pasien.

Penghentian Terapi Bantuan Hidup dimaknai sempit oleh banyak pihak sebagai perilaku mengakhiri kehidupan dengan sengaja oleh seseorang. Hal ini menyebabkan isu Penghentian Terapi Bantuan Hidup menjadi sensitif dan penuh kontroversial untuk dibicarakan di lingkungan yang masih konservatif. Persoalan menjelang akhir kehidupan makin menjadi isu yang penuh dengan pendapat dan tak jarang bertentangan satu sama lain. Maka dari itu penulis memandang penting untuk membahas tindakan dalam Penghentian Terapi Bantuan Hidup (Withdrawing of life support) dalam Perawatan Paliatif sebagai upaya lebih mempertegas hak pasien yang membutuhkan penghormatan dan kedamaian di akhir masa hidupnya dan memberikan perlindungan hukum yang lebih detail pada dokter dalam menjalankan profesinya.

\footnotetext{
${ }^{1}$ Gunawandi, Hukum Medik (Medical Law), Penerbit Buku Kesehatan Fakultas Ilmu Kedokteran Universitas Indonesia, Jakarta, 2007, h. 246
} 


\section{TINJAUAN TEORITIS}

\section{A. Penghentian Terapi Bantuan Hidup}

Penghentian Terapi Bantuan Hidup (Withdrawing of life support) adalah proses mengabaikan atau menghentikan terapi bantuan hidup, dengan konsekuensi medis bahwa kemungkinan pasien mengalami kematian alami akibat penyakit yang mendasari atau komplikasi terkait. ${ }^{2}$ Dalam Ketentuan Umum Pasal 1 Peraturan Menteri Kesehatan Nomor 37 tahun 2014 tentang Penentuan Kematian dan Pemanfaatan Organ Donor (selanjutnya disebut Permenkes Penentuan Kematian dan Pemanfaatan Organ Donor) dijelaskan bahwa "Penghentian Terapi Bantuan Hidup adalah menghentikan sebagian atau semua terapi bantuan hidup yang sudah diberikan kepada pasien". Poin berikutnya tertulis "Penundaan terapi bantuan hidup adalah menunda pemberian terapi bantuan hidup atau lanjutan tanpa menghentikan terapi bantuan hidup yang sedang berjalan". Dalam Pasal 14 angka (5) dijelaskan secara rinci jenis bantuan hidup lanjut dan perawatan yang bersifat luar biasa (extra-ordinary) meliputi:

a. Rawat di Intensive Care Unit;

b. Resusitasi Jantung Paru;

c. Pengendalian disritmia;

d. Intubasi trakeal;

e. Ventilasi mekanis;

f. Obat vasoaktif;

g. Nutrisi parenteral;

h. Organ artifisial;

i. Transplantasi;

j. Transfusi darah;

k. Monitoring invasive;

1. Antibiotika;

m. Tindakan lain yang ditetapkan dalam standar pelayanan kedokteran.

Sedangkan dalam Pasal 14 angka (6) dicantumkan perawatan hidup dasar (ordinary) yang tidak dapat dihentikan atau ditunda meliputi oksigen, nutrisi enteral dan cairan kristaloid.

\section{B. Perawatan Paliatif}

World Health Organization memberikan definisi terapi paliatif sebagai pendekatan yang meningkatkan kualitas hidup pasien dan keluarganya menghadapi masalah penyakit yang mengancam nyawa, baik melalui pencegahan maupun mengurangi penderitaan dengan langkah identifikasi awal dan penilaian dampak serta penanganan nyeri dan masalah lainnya seperti psikososial dan spiritual. ${ }^{3}$ Sedangkan menurut Keputusan Menteri Kesehatan Nomor 812 tahun 2007 tentang Perawatan Paliatif, mempunyai pengertian suatu pendekatan yang bertujuan memperbaiki kualitas hidup pasien dan keluarga yang menghadapi masalah yang berhubungan dengan penyakit yang dapat mengancam jiwa, melalui pencegahan dan peniadaan melalui identifikasi dini dan penilaian yang tertib serta penanganan nyeri dan masalah-masalah lain, fisik, psikososial dan spiritual. Tujuan perawatan paliatif adalah untuk meningkatkan kualitas hidup pasien dalam menghadapi setiap penyakit yang diderita dan menyiapkan diri menghadapi kematian dengan tenang dan nyaman tanpa merasa tertekan atas penyakit yang diderita baik secara fisik (nyeri, mual, muntah) maupun psikis yang berbasis spiritual. ${ }^{4}$ Secara terperinci prinsip prinsip perawatan paliatif adalah:

1. Mengurangi rasa sakit dan gejala tidak nyaman lainnya.

2. Menegaskan arti kehidupan dan memandang kematian sebagai suatu proses yang normal.

3. Tidak bertujuan mempercepat atau menunda kematian.

4. Memadukan aspek biopsikologi, sosial dan spiritual dalam pengobatan.

5. Menawarkan dukungan untuk membantu pasien hidup seaktif mungkin sampai meninggal.

6. Menawarkan dukungan agar keluarga pasien tabah selama pasien sakit dan saat kehilangan.

7. Menggunakan pendekatan tim untuk menjawab kebutuhan pasien dan keluarga, termasuk dukungan saat sedih dan kehilangan jika diperlukan.

8. Meningkatkan kualitas hidup, memberi pengaruh positif selama sakit.

9. Dapat diterapkan sejak awal pengobatan, bersamaan dengan terapi terapi lain yang bertujuan memperpanjang hidup misalnya kemoterapi atau radiasi. ${ }^{5}$

Dalam konteks pasien kondisi kritis saat stadium akhir dimana pasien sudah tidak dapat ditolong secara medis dan sudah mendekati ajal, perlu diberikan toleransi dan kelonggaran terkait dosis untuk memperoleh obat penghilang nyeri dan penenang yang sangat mungkin dosis tersebut menyebabkan kematian. ${ }^{6}$

\footnotetext{
${ }^{2}$ Bandraouk Dowener, Withholding and Withdrawing of Life-Sustaining Treatment: The Canadian Critical Care Society Position Paper, 2017, h. 2

${ }^{3}$ Liliana De Lima, International Association for Hospice and Palliative Care Position Statement: Eutanasia and Physician-Assisted Suicide, Journal of Palliative Medicine, Volume 20, Number 1, 2017. 10

${ }^{4}$ Radhakrishnan K, Van Scoy, Jillapalli, Community Based Game Intervention to Improve South Asian Indian American's Engegement With Advanced Care Planning, Ethn Heal, 2017, h. 19

${ }^{5}$ Hamzah Satri, Edward Faisal, Rudi Putranto, Advanced Directives Pada Pasien Perawatan Paliatif, Jurnal Penyakit Dalam Indonesia, Volume 7, Nomor 2, Juni 2020, h. 127
} 
Website : http://yustisia.unmermadiun.ac.id/index.php/yustisia

\section{Kondisi Terminal}

Kondisi terminal adalah kondisi akhir kehidupan sebelum kematian akibat penyakit yang tidak dapat disembuhkan. Kondisi terminal ditandai dengan gangguan berat atau kegagalan sebagian besar fungsi organ tubuh karena kekurangan oksigen (hypoxia) secara luas. Tanda ini meliputi adalah menurunnya kesadaran dan reflek tubuh, gangguan napas dan pompa jantung. Lama berlangsungnya kondisi terminal ini sangat tergantung dari kegawatan penyakit yang mendasari dan tindakan medis yang diberikan termasuk pijat jantung, napas buatan dan obat pacu jantung yang sebenarnya adalah sia sia (futile). ${ }^{7}$ Dalam Pasal

Peraturan Menteri Kesehatan Nomor 37 Tahun 2014 tentang Penentuan Kematian dan Pemanfaatan Organ Donor disebutkan

"Pada pasien yang berada dalam keadaan tidak dapat disembuhkan akibat penyakit yang dideritanya (terminal state) dan tindakan kedokteran sudah sia sia (futile) dapat dilakukan penghentian atau penundaan terapi bantuan hidup". Kondisi terminal adalah suatu keadaan dimana seseorang menderita penyakit yang tidak memiliki harapan sembuh sehingga sangat dekat dengan proses kematian. Respon tubuh pasien dalam kondisi terminal sangat individual tergantung kondisi fisik, psikologis, social yang dialami sehingga dampak yang muncul pada setiap individu juga berbeda.

\section{Teori Kemanfaaatan}

Aliran Utilitarianisme mempunyai pandangan bahwa tujuan hukum adalah memberikan kemanfaatan sebanyak-banyaknya. Kemanfaatan di sini diartikan sebagai kebahagiaan (happines), sehingga penilaian terhadap baik-buruk atau adil-tidaknya suatu hukum bergantung kepada apakah hukum itu memberikan kebahagiaan kepada manusia atau tidak. Dengan demikian berarti bahwa setiap penyusunan produk hukum (peraturan perundang-undangan) seharusnya senantiasa memperhatikan tujuan hukum yaitu untuk memberikan kebahagiaan sebanyak banyaknya bagi masyarakat. ${ }^{8}$

\section{III.METODE PENELITIAN}

Penelitian ini merupakan penelitian yuridis normatif yaitu penelitian yang membahas doktrin-doktrin atau azas-azas dalam ilmu hukum, dengan pengertian pokok dasar hak dan kewajiban, peristiwa hukum, hubungan hukum dan objek hukum. Penelitian ini mengkaji pada norma-norma hukum yang terdapat dalam peraturan perundang-undangan tertentu secara hukum tertulis dan sistematis.

Pendekatan yang digunakan dalam penelitian ini adalah pendekatan perundang-undangan (statute approach) yaitu pendekatan yang mengkaji tentang asas-asas hukum, norma-norma hukum dan peraturan perundang-undangan serta pendekatan konseptual (conceptal approach) yaitu mengadakan identifikasi terhadap pengertian-pengertian pokok dasar dalam hukum yakni subyek hukum, hak dan kewajiban, peristiwa hukum, hubungan hukum dan obyek hukum. Kami juga menggunakan pendekatan komparatif (comparative approach) untuk mengkaji perbandingan isu hukum dengan beberapa negara lain yang terlebih dahulu melegalkan tindakan euthanasia secara luas. ${ }^{9}$ Bahan hukum dalam penelitian ini terdiri dari bahan hukum primer, bahan hukum sekunder dan bahan hukum tersier. Tipe penelitian ini merupakan penelitian yuridis normatif yaitu penelitian yang membahas doktrin-doktrin atau azas-azas dalam ilmu hukum, dengan pengertian pokok dasar hak dan kewajiban, peristiwa hukum, hubungan hukum dan objek hukum. Penelitian ini mengkaji pada norma-norma hukum yang terdapat dalam peraturan perundang-undangan tertentu secara hukum tertulis dan sistematis. ${ }^{10}$

Dalam proses pengumpulan bahan hukum, peneliti menggunakan studi dokumen, yaitu mengumpulkan bahan-bahan hukum kepustakaan yang berupa peraturan perundang-undangan, buku-buku hukum, jurnal, literatur, dan kamus hukum, kamus bahasa Indonesia dan buku ajar keperawatan. Adapun langkah-langkah pengumpulan bahan hukum meliputi: membaca, mempelajari, mengutip, menghubungkan bahan-bahan hukum dari bahan hukum primer, bahan hukum sekunder serta bahan hukum tersier sehingga menjadi satu kesatuan sehingga mudah dalam pengertian yang disampaikan.

\section{IV.ANALISIS DAN PEMBAHASAN}

\section{A. Norma Hukum Penghentian Terapi Bantuan Hidup dalam Perawatan Paliatif di Indonesia.}

Praktek Penghentian Terapi Bantuan Hidup menjadi tahapan akhir dalam perawatan pasien pasien terminal yang sudah tidak memiliki harapan kesembuhan dan menjadi kontroversi apakah dapat menjadi tahapan akhir dalam Perawatan Paliatif. Tentunya hal ini harus melalui proses kajian yang mendalam dari sisi keilmuan kedokteran, dengan kriteria-kriteria terukur dan syaratsyarat yang amat detail.

Perawatan ordinary adalah segala tindakan medis yang ditujukan untuk memenuhi kebutuhan dasar tubuh yang wajar, yang dapat diperoleh atau dilakukan tanpa biaya berlebihan, tanpa menimbulkan ketidaknyamanan lain. Sedangkan tindakan yang

\footnotetext{
${ }^{6}$ Kartono M, Tehnologi Kedokteran dan Tantangannya Terhadap Bioetika, PT. Gramedia Pustaka Utama, Jakarta, 1992

${ }^{7}$ Hui, David; Nooruddin, Zohra; Didwaniya, et all;" Concepts and Definitions for Actively Dying, End of Life, Terminally Ill, Terminal Care, and Transition of Care, A Systematic Review". Journal of Pain and Symptom Management. Volume 47 (1); 2014: 77-89

${ }^{8}$ Okorie, Ndukaku, How Impartialist is the Utilitarian Principle of Utility?, International Journal of Humanities and Social Science, Volume 10, Number. 10, October 2020

${ }^{9}$ Peter Mahmud Marzuki, Penelitian Hukum, Kencana Prenada Media Group, cetakan II, Jakarta, 2005, h.59-60.

${ }^{10}$ Zainudin Ali, Metode Penelitian Hukum, Sinar Grafika. Jakarta 2015 hal 25-26
} 
extraordinary adalah semua tindakan medis, bedah atau obat-obatan yang diperoleh atau dilakukan dengan biaya berlebih, susah payah dan ketidaknyamanan, atau yang apabila dilakukan tidak menawarkan harapan "perbaikan keadaan" yang wajar. ${ }^{11}$ Prinsip Perawatan Paliatif masih melanjutkan perawatan yang ordinary sebagai bentuk menjaga kualitas hidup pasien, sedangkan perawatan yang extraordinary yang dirasakan tidak bermanfaat dapat dihentikan karena bertentangan dengan prinsip Perawatan Paliatif. Penentuan mana yang ordinary atau extraordinary menjadi sangat penting agar para dokter dan perawat yakin bahwa tindakan profesionalnya tidak melanggar etika maupun hukum. Artinya pilihan penghentian tindakan yang bersifat extraordinary dengan tetap melakukan tindakan yang ordinary, masih menunjukan upaya perawatan pada masa akhir kehidupan pasien. Berbeda halnya jika penundaan atau penghentian tersebut dilakukan pada tindakan yang ordinary, maka bisa digolongkan sebagai tindakan pembunuhan.

Ditinjau dari delik adat masyarakat di Indonesia yang masih dipegang teguh, suatu perbuatan akan mengandung sanksi dari masyarakat karena tidak sesuai dengan kebiasaan norma yang ada pada masyarakat dan dianggap mengganggu keseimbangan masyarakat. Sanksi ini perlu diberikan sebagai upaya penyelesaan dengan tujuan agar keseimbangan masyarakat tidak terganggu. Dalam hukum delik adat masyarakat masih memegang teguh sifat sifat nilai tradisional religious, yang tidak menyamaratakan, terbuka dan fleksibel. ${ }^{12}$

Jika Penghentian Terapi Bantuan Hidup dipraktekkan di Indonesia dan dianggap sebagai suatu delik adat, berdasar pemikiran “tidak menyamaratakan", maka seharusnya perlu dipikirkan siapa dan apa yang melatarbelakangi tindakan ini. Penghentian Terapi Bantuan Hidup dalam Perawatan Paliatif diputuskan melalui kajian dokter yang memiliki latar belakang keilmuan kesehatan lebih dibandingkan masyarakat umum. Begitu pula pertimbangan belas kasihan atas penderitaan pasien dan keluarganya, apalagi atas permintaan yang jelas dari yang bersangkutan atau keluarganya. Tindakan tersebut tidak akan menyebabkan gangguan keseimbangan mengingat pasien atau keluarga sebagai pihak "korban" justru menghendakinya. Terlebih pasien memiliki ciri khusus yaitu dalam kondisi terminal, sangat menderita dan menurut ilmu pengetahuan kedokteran penyakitnya sudah tidak dapat disembuhkan lagi. Sangat tidak adil jika kita menyamakan kondisi tersebut dengan kondisi manusia normal.

Perilaku manusia merupakan pengejawantahan dari fungsi jiwa, yaitu melalui proses berfikir dan berperasaan secara sadar. Proses berpikir dibawah sadar memegang peran penting dalam penjelmaan perilaku. Dari segi sikap batin dokter yang melaksanakan Penghentian Terapi Bantuan Hidup, tidak ada seorang dokter yang menginginkan pasiennya tidak sembuh dari penyakit yang diderita. Begitupun tidak ada seorang dokter yang berniat membunuh pasiennya untuk kepentingan dirinya. Pada tindakan Penghentian Terapi Bantuan Hidup betul betul dipertimbangkan demi kepentingan pasien, sehingga tidak tepat kalau Tindakan ini dianggap suatu pembunuhan.

Motivasi utama dilakukannya Penghentian Terapi Bantuan Hidup adalah untuk membebaskan penderitaan pasien di akhir masa kehidupannya, jelas sangat berbeda dengan pembunuhan. Tujuan yang beriorientasi pada kebaikan pasien justru sangat mulia. Dengan demikian, tujuan mulia ini sangat tidak pantas jika dipandang sebagai tindakan kriminal dengan ancaman hukuman. Dokter tidak seharusnya dipersalahkan jika terjadi kegagalan dalam mengobati pasien hingga berhadapan dengan kematian, selama segala upaya telah dilaksanakan sesuai prosedur. ${ }^{13}$

Dalam Perawatan Paliatif tidak selamanya tindakan pengobatan menghasilkan hal yang diharapkan untuk mencapai kualitas hidup yang diinginkan. Kondisi pasien yang sudah tidak berespon dengan upaya medis maksimal seringkali di pandang menghasilkan kesiasiaan yang menambah panjang penderitaan pasien. Ibarat labirin yang berputar putar, upaya medis hanya menghasilkan perpanjangan hidup semu semata yang tidak memperdulikan kualitas hidup pasien. ${ }^{14}$ Jika hal ini tetap dipaksakan justru bertentangan dengan prinsip Perawatan Paliatif sendiri yaitu tidak bertujuan mempercepat atau menunda kematian. Pasien dengan kondisi terminal dengan upaya medis yang dinilai tidak bermanfaat dan sia sia pasti mempunyai kondisi klinis yang sangat beragam dan individual.

\section{B. Penghentian Terapi Bantuan Hidup di Kanada.}

Etika biomedis di Kanada tidak menganggap Penghentian Terapi Bantuan Hidup (Withdrawing of life support) sebagai penyebab kematia, tetapi karena proses penyakit yang mendasarilah yang bertanggung jawab atas kematian. Terlebih Kanada sejak tahun 2016 Mahkamah Agung Kanada telah melegalkan Medical Assistance in Dying (MAID) yaitu perbuatan menghilangkan nyawa atas permintaan sendiri yang dibantu dokter. Perbuatan ini sebelumnya termasuk dalam tindak pidana pasal 241 huruf (b) Canadian Criminal Code di Kanada, namun sejak diamandemen pada Juni 2016 maka Parlemen Kanada resmi mengesahkan Undang Undang yang melegalkan eutanasia dalam bidang medis dengan berbagai persyaratan dan menunjuk pusat pusat layanan kesehatan yang memiliki kewenangan itu.

Menurut Undang-Undang tersebut setiap orang bersalah atas pelanggaran yang dapat didakwa dan dapat dihukum penjara untuk jangka waktu tidak lebih dari 14 tahun yang, apakah bunuh diri terjadi atau tidak termasuk menasihati seseorang untuk bunuh diri, mendukung seseorang untuk bunuh diri, atau membantu seseorang mati karena bunuh diri. Pengecualian dalam bidang

\footnotetext{
${ }^{11}$ O'Rourke K.A, Primer for Health Care Ethics. Essays for Pluralistic Society. Washington DC: Georgetown University Press; 2000.

${ }^{12}$ Hadikusumo, Hilman, Pengantar Ilmu Hukum Adat Indonesia, CV Mandar Maju, Bandung, 2014, h. 233.

${ }^{13}$ Richard A. Muller, Keith Phoenix, A Dilemma for the Legal and Medical Professions, Euthanasia and the Defective Newborn, Aspen Publication, London, 1980 , p. 335

${ }^{14}$ Chunmei Lyu, Li Zhang, Who Decides in Withdrawal of Treatment in a Critical Care Setting?A Case Study on Ethical Dilemma, International Journal of Nursing Sciences, Volume 5, 2018, p. 310-314
} 
medis saat pasien sekarat, tidak ada praktisi medis atau perawat yang melakukan pelanggaran jika mereka tidak memberikan bantuan medis kepada seseorang dalam keadaan sekarat.

Saat pelaksanaan Penghentian Terapi Bantuan Hidup, tim medis di Kanada dapat menggunakan opioid dan obat penenang dosis tinggi untuk meredakan penderitaan. Meskipun opioid dan tobat penenang tidak secara rutin mempercepat kematian saat dititrasi untuk mencapai kenyamanan, ada kemungkinan bahwa obat-obatan ini secara tidak sengaja dapat mempercepat kematian pasien. The Doctrine of Double Effect menyatakan bahwa obat tersebut sebagai obat "penghibur" untuk menenangkan pasien meskipun sejatinya juga berpotensi mempercepat kematian. Upaya ini membawa dampak kematian namun boleh dilakukan karena tidak dimaksudkan untuk mempercepat proses kematian, tetapi lebih berfokus pada memaksimalkan kenyamanan pasien

Di Kanada pihak pasien dapat saja tidak ingin mengetahui atau terlibat dalam keputusan tindakan Penghentian Terapi Bantuan Hidup. Meskipun tim Dokter ingin menyampaikan agar pasien dilibatkan dalam keputusan pengobatan mereka sendiri, tetapi pada akhirnya mereka harus menghormati keputusan pasien untuk tidak terlibat. Seorang dokter yang mengesampingkan preferensi ini dianggap tidak menghormati otonomi pasien. Dokter diberikan legalitas secara hukum untuk dapat menentukan hal ini. Dokter dapat berbicara dengan pasien dengan tujuan pasien mengetahui semua tentang kondisi mereka dan pilihan pengobatan. Namun pasien dapat memilih untuk bersikap tidak ingin tahu dan membuat keputusan sepenuhnya kepada keluarga mereka. Otonomi pasien diberikan tempat sedemikian luas untuk menentukan apa yang terbaik bagi pasien. Tersedia Layanan Kesehatan

Spiritual sebagai sumber daya untuk mengeksplorasi, menilai dan memberikan bantuan bagi pasien dan keluarga. Institusi Kesehatan Wilayah secara periodik menetapkan proses pelaporan di antara pusat kesehatan yang secara teratur meninjau masalah ini dari waktu ke waktu dan retrospektif. Khusus untuk pasien stabil, bila tidak ada tekanan waktu yang signifikan, perselisihan harus ditangani dengan pendapat dokter tambahan. Ini meningkatkan transparansi dan kepatuhan terhadap standar praktik kedokteran. Ini juga menghilangkan persepsi pengambilan keputusan sepihak.

Tim dokter juga harus terbiasa dengan proses resolusi konflik antara mereka. Penting untuk menyadari perbedaan pendapat dan tetap perpedoman pada kebijakan Undang Undang Negara Bagian dan Peraturan Provinsi yang terkait dengan Penghentian Terapi Bantuan Hidup. ${ }^{15}$ Keputusan mengenai Terapi Bantuan Hidup harus ditinjau jika ada perubahan signifikan atau tak terduga pada kondisi pasien yang mungkin mengubah prognosis yang disebutkan sebelumnya yang menjadi dasar rencana perawatan sebelumnya.

Penghentian Terapi Bantuan Hidup atas permintaan dari pasien yang kompeten merupakan hak individu pasien. Di Kanada pasien secara penuh berhak untuk mengabaikan atau meminta penarikan semua bentuk intervensi medis, termasuk Terapi Bantuan Hidup. Keputusan harus diinformasikan dan sukarela, dan tanpa paksaan, dan sebaiknya dibuat ketika kompetensi dan kemampuan pasien untuk berkomunikasi tidak terganggu. Ketika anggota keluarga mengungkapkan keinginan pandangan yang berlawanan dengan yang diungkapkan oleh pasien yang kompeten, pandangan ini harus dicatat dan didiskusikan, tetapi tetap mengutamakan dan tidak mengesampingkan pilihan yang diungkapkan oleh pasien. Jika pasien yang kompeten berubah pikiran tentang keinginan yang diungkapkan, keinginan terbaru yang diungkapkan dianggap berlaku dalam konteks perawatan yang ditawarkan, sekalipun bertentangan dengan keputusan sebelumnya.

Keputusan Penghentian Terapi Bantuan diambil melalui proses diskusi dan komunikasi pendahuluan bagi pasien untuk menetapkan tujuan, nilai, dan preferensi perawatan mereka. Ini melibatkan tim medis dan sering kali didokumentasikan secara tertulis. Dokumentasi ini dapat berupa Arahan (Directive), Surat Wasiat (Living Wills) atau Rencana Perawatan (Care Plan). Arahan (Directive) adalah dokumen yang dibuat oleh individu yang kompeten mengenai keputusan perawatan kesehatan yang akan dibuat jika individu tersebut menjadi tidak kompeten untuk membuat keputusan tersebut. Tujuan dari Directive adalah untuk menjaga otonomi pasien bahkan ketika dia kehilangan kapasitas pengambilan keputusan. Ini ditujukan kepada keluarga pasien dan tim perawatan kesehatan. Salinan arahan ini dibuat pasien ketika dia dirawat di fasilitas perawatan kesehatan. Ini juga d apat menentukan nilai atau instruksi pasien yang harus digunakan untuk memandu keputusan perawatan kesehatantentang apa yang ingin atau tidak ingin diterima pasien. Arahan tidak dapat memaksa tim perawatan kesehatan untuk memberikan perawatan yang berada di luar Standar Perawatan.

Jika tidak ada Arahan (Directive) tertulis, pasien yang kompeten dan berpengetahuan dapat menyampaikan keinginan dan preferensi mereka secara lisan, dan arahan verbal ini harus memandu perawatan dengan cara yang sama seperti instruksi tertulis. Namun, percakapan ini harus didokumentasikan sesuai dengan kebijakan kelembagaan sehingga dapat menginformasikan pertemuan perawatan kesehatan di berikjutnya. Secara umum, pernyataan yang dibuat oleh pasien yang dalam kondisi tidak berdaya (dalam kaitannya dengan penyakit atau pengobatan akut, dan karena itu kemungkinan besar dapat diubah) tidak menggantikan pernyataan pasien sendiri sebelumnya ketika mereka kompeten. Namun, bila terjadi ketidaksesuaian, dokter harus mempertimbangkan konteks klinis dan anggapan kepentingan terbaik pasien. Jika tidak ada arahan yang jelas dan relevan, Dokter harus menerapkan standar "kepentingan terbaik". Standar ini mencakup pertimbangan kesejahteraan pasien secara keseluruhan, nilai dan keyakinan umum mereka, serta potensi beban dan manfaat dari pilihan pengobatan

\section{Analisis Komparatif Penghentian Terapi Bantuan Hidup di Indonesia dengan Kanada.}

Di Indonesia Tindakan Penghentian Terapi Bantuan Hidup dalam bidang medis diatur dalam peraturan setingkat Peraturan Menteri Kesehatan, sedangkan di Kanada sudah diatur pada peraturan setingkat Undang Undang dalam Canadian Criminal Code. Disebutkan dalam Undang Undang ini pasien yang boleh mengakhiri hidup adalah mereka yang mengalami penderitaan panjang

\footnotetext{
${ }^{15}$ Schedule D, Withholding and Withdrawing Life Sustaining Treatment, Standards of Practice of Medicine, CPSM By Law, 2008.
} 
dan tidak dapat ditolerir. Secara garis besar batasan Penghentian Terapi Bantuan Hidup di Indonesia memiliki kemiripan dengan Kanada yaitu suatu keadaan dimana seorang dokter atau tenaga medis lainnya secara sengaja menahan atau tidak memberikan terapi bantuan hidup lebih lanjut terhadap pasien dengan pertimbangan upaya medis tersebut sia sia. Di Indonesia tidak semua tindakan perawatan dihentikan sama sekali, melainkan tetap memberikan perawatan dasar dengan maksud untuk membantu pasien dalam fase hidupnya yang terakhir. Hal ini yang membedakan dengan Kanada yang memang secara hukum begara ini melegalkan uetanasia di bidang medis.

Pada Penghentian Terapi Bantuan Hidup di Indonesia, dokter tidak memberikan tindakan secara aktif dalam mempercepat proses kematian pasien. Apabila seorang pasien menderita penyakit dalam stadium terminal, yang menurut pendapat dokter tidak mungkin lagi disembuhkan, maka dokter selalu memberikan informasi dan edukasi kepada pihak keluarga terkait upaya maksimal yang sudah dilakukan, harapan kesembuhan terkait upaya tersebut, dan rencana perawatan medis berikutnya. Melanjutkan upaya medis tersebut dirasakan tidak bermanfaat dan sia sia karena tidak mendapatkan hasil seperti yang diharapkan sesuai dengan bidang keilmuan kedokteran. Tindakan penghentian seperti ini termasuk kepada Penghentian Terapi Bantuan Hidup.

Tujuan yang utama dari Penghentian Terapi Bantuan Hidup adalah menghentikan penderitaan pasien dan menghentikan upaya medis yang dirasa sia-sia, sedangkan tujuan perawatan paliatif juga memberikan kenyamanan pasien dalam menghadapi kematian. Jadi sebetulnya tindakan Penghentian Terapi Bantuan Hidup sedikit banyak dapat menjadi bagian dan dapat digolongkan kedalam Perawatan Paliatif. Justru dengan meneruskan upaya extraordinary yang dirasakan sia sia akan bertolak belakang dengan konsep Perawatan Paliatif yaitu tidak bertujuan mempercepat atau menunda kematian pasien. Dengan tindakan menghentikan (withdrawing) terapi bantuan hidup yang bersifat extraordinary maka tubuh akan menentukan sendiri waktu kematian yang dianggap wajar dan dipandang kematian merupakan proses akhir kehidupan yang alamiah.

Memang dalam pembicaraan Perawatan Paliatif sangat ditekankan masalah kualitas hidup dari pasien. Pada stadium terminal, pasien dengan penyakit kronis tidak hanya mengalami berbagai masalah fisik seperti nyeri, patensi jalan napas, sirkulasi tubuh dan kegagalan multi organ yang kompleks, tetapi juga mengalami gangguan psikososial dan spiritual yang mempengaruhi kualitas hidup pasien dan keluarganya. Maka kebutuhan pasien pada stadium terminal suatu penyakit adalah mengurangi, menghentikan atau setidaknya tidak memperpanjang penderitaan pasien diakhir masa kehidupannya, disamping juga dukungan terhadap kebutuhan psikologis, sosial dan spiritual yang dilakukan dengan pendekatan interdisiplin yang dikenal sebagai perawatan paliatif.

Meskipun ada beberapa pandangan melalui berbagai artikel tentang isu ini yang menyatakan bahwa tidak ada tempat bagi Penghentian Terapi Bantuan Hidup dalam Perawatan Paliatif, namun penulis berpendapat bahwa sejatinya tetap ada tempat bagi tindakan Penghentian Terapi Bantuan Hidup dalam Perawatan Paliatif sebagai upaya terakhir menyiapkan pasien menghadapi kematian sebagai proses yang wajar dalam kehidupan. Yang menjadi masalah berikutnya adalah terapi bantuan hidup yang mana yang dapat dihentikan dan mana yang tidak. Penghentian Terapi Bantuan Hidup menjadi pilihan terakhir dalam fase Perawatan Paliatif ketika pasien sudah tidak mempunyai harapan sembuh dan seluruh tindakan medis dirasa sia sia, karena melanjutkan usaha yang sia sia ini justru akan menambah panjang penderitaan pasien dan meninggalkan beban masalah yang kompleks pada keluarga pasien. Tindakan menghentikan terapi bantuan hidup ini sebagai bentuk menghormati martabat pasien dengan tidak memperpanjang usaha yang sia sia menghadapi kondisi penyakit yang sudah tidak ada harapan membaik apalagi sembuh.

Pertimbangan utama rasa belas kasihan merupakan keyakinan moral bahwa tidak manusiawi memaksakan kehidupan dengan segala cara ketika seorang pasien dihadapkan dengan situasi penderitaan dan kesusahan yang timbul dari penyakit yang tidak dapat disembuhkan. Menghentikan bantuan hidup yang dirasa sia sia dipandang lebih baik, lebih bermanfaat dan lebih menghormati martabat pasien untuk menjalani akhir kehidupan daripada memaksakan kehidupan yang kualitasnya pun tidak layak.

Dalam paham utilitarian menurut Bentham satu prinsip moral yang utama, yakni “prinsip utilitas”. Prinsip utilitas diartikan sebagai pilihan yang dapat menghasilkan keuntungan, kemanfaatan, kenikmatan dan kebahagiaan bagi semua atau sebagian besar pihak dan mencegah terjadinya kerusakan, kesakitan, kejahatan atau ketidakbahagiaan. Sepaham dengan itu, Stuart Mill berpendapat bahwa aturan pertama moralitas adalah bertindak sedemikian rupa untuk menghasilkan kesejahteraan terbesar, sejauh hal itu dimungkinkan. Oleh karena itu, dalam memutuskan apa yang harus dilakukan setiap orang harus mempertimbangkan pilihan perilaku manakah yang akan menghasilkan kebahagiaan terbesar untuk semua orang. Moralitas utilitarian mempunyai gagasan bahwa penganutnya harus memperhatikan kesejahteraan setiap orang secara merata. Seperti yang ungkapkan Mill bahwa kita harus bersikap semaksimal mungkin tidak berpihak, sebagai pengamat yang tanpa pamrih dan baik hati. ${ }^{16}$ Artinya pilihan yang berorientasi pada manfaat bagi banyak pihak tersebut tetap bersandar pada keilmuan dan profesionalisme.

Pertimbangan-pertimbangan yang ditekankan oleh paham utilitarianisme adalah kesejahteraan atau kebahagiaan sebanyak mungkin orang. Prinsip ini mendorong kita dalam menentukan pilihan tindakan yang mempunyai konsekuensi terbaik bagi setiap orang dalam menghadapi pilihan diantara tindakan-tindakan alternatif atau kebijakan sosial. Jika kita telaah, dasar pilihan tindakan. Penghentian Terapi Bantuan Hidup pada pasien terminal ini bersifat teleologis atau konsekuensialis, yaitu memandang suatu tindakan itu baik apabila hasil atau konsekuensi dari tindakan itu menghasilkan keuntungan atau kesejahteraan sebanyak mungkin orang. Menghentikan upaya terapi bantuan hidup pada pasien kondisi terminal seolah menjawab ketidakpastian sampai kapan keberlangsungan tubuh pasien menjalani akhir kehidupannya. Secara umum utilitarianisme membawa suatu prinsip etis yang lebih rasional, mengedepankan aspek sosial (kebaikan sebanyak mungkin orang), dan menekankan aspek universalitasnya.

\footnotetext{
${ }^{16}$ Tim Mulgan, Understanding Utilitarianism, Acumen Press, Stocksfield, 2007, h. 10.
} 
Utilitarianisme merupakan suatu prinsip etis yang bermutu tinggi karena merupakan kesimpulan dari kewajiban kita untuk bertanggungjawab terhadap sesama yaitu terhadap siapa saja kita hendaknya selalu mengambil sikap baik. ${ }^{17}$

Oleh sebab itu utilitarisme mengkaitkan moralitas suatu tindakan dengan jumlah akibat baik yang melebihi akibat buruknya, maka pertanyaan yang muncul selanjutnya adalah bagaimana nilai suatu akibat itu dapat ditentukan. Pertanyaan ini harus dapat dijawab kalau kaidah utilitarianisme mau dipakai. Kalau kita mau memakai kelebihan akibat baik terhadap akibat buruk sebagai tolok ukur moral, maka kita harus paham arti "lebih besar" dalam hubungan dengan nilai. Menghitung akibat-akibat tersebut dengan perbandingan kuantitas sudah tentu kita akan menghadapi kesulitan. Manfaat ada bermacam-macam dan sulit dibandingkan. Kesulitan menjadi lebih besar lagi kalau masih harus membandingkan besar-kecilnya akibat baik dan akibat buruk yang ditimbulkannya. Mengambil keputusan tindakan Penghentian Terapi Bantuan Hidup tentu memunculkan peredebatan dalam mengkomparasi nilai hak asasi untuk hidup, kemanusiaan, dan pertimbangan psikososial ekonomi keluarga pasien, mana yang lebih dikedepankan.

Kelemahan yang biasa dikemukakan terhadap teori utilitarisme adalah bahwa kaidah dasar yang dikemukakan oleh teori tersebut dapat dipandang bertentangan atau kontradiksi dengan prinsip keadilan. Keadilan yang dimaksud adalah adanya sebagian pihak meskipun kecil yang mungkin dikalahkan kepentingannya. Mungkin Penghentian Terapi Bantuan Hidup dalam dunia kesehatan dianggap melanggar hak asasi pasien dan melawan Tuhan, namun bagaimana bisa menghormati hak asasi pasien sedangkan intervensi medis yang diberikan justru akan menambah panjang penderitaan bagi pasien tanpa membawa manfaat apa apa secara keilmuan. Tindakan penundaan atau penghentian itu dilakukan pada tindakan yang bersifat penyembuhan (cure) dan bukan pada perawatan (care). Oleh karena itu oksigen, nutrisi enteral dan cairan tetap diberikan sebagai penghormatan martabat pasien yang masih dijunjung tinggi.

Keputusan untuk menghentikan suatu peralatan atau tindakan memperpanjang hidup pada pasien memang akan selalu menimbulkan perdebatan. Berbagai pertimbangan harus dikaji, apakah tindakan tersebut sebagai perawatan (care) ataukah penyembuhan (cure). Apabila merupakan bagian dari penyembuhan (cure) dan dianggap sebagai tindakan medis yang tidak memberikan manfaat atau sia-sia maka dapat dihentikan, tetapi apabila dianggap sebagai bagian dari perawatan (care) maka oleh alasan apapun tidak bisa dibenarkan bila dihentikan karena tidak melaksanakan upaya menjaga kebutuhan hidup dasar dalam rangka menghormati martabat pasien.

Norma hukum di Kanada sebagai negara yang melegalkan eutanasia, mengijinkan Penghentian Terapi Bantuan Hidup baik itu yang bersifat pengobatan (care) maupun perawatan (care) bahkan dimungkinkan memberikan obat penenang dan anti nyeri dosis tinggi yang berefek kematian pada masa akhir kehidupan pasien. Berbeda dengan norma hukum di Indoensia yang belum mengatur masalah euthanasia secara khusus, Tindakan Penghentian Terapi Bantuan Hidup diatur dengan membatasi penghentian terapi yang bersifat extraordinary namun tetap memberikan terapi yang bersifat ordinary.

\section{Pertanggungjawaban Hukum Pidana bagi Dokter Sebagai Pelaku Penghentian Terapi Bantuan Hidup.}

Perbuatan hukum adalah setiap perbuatan manusia yang dilakukan dengan sengaja untuk memperoleh suatu akibat yang diatur oleh hukum. Sementara akibat hukum adalah akibat yang ditimbulkan dari suatu tindakan hukum. ${ }^{18}$ Perihal tentang hilangnya nyawa orang lain dalam Kitab Undang-Undang Hukum Pidana (KUHPidana) diatur dalam Bab XIX Pasal 338 sampai dengan Pasal 340, Pasal 344 sampai dengan Pasal 345, Bab XX Pasal 359 dan Pasal 361 yang digolongkan kedalam kejahatan terhadap nyawa. Berikut ini adalah uraian tentang pengaturan hilangnya nyawa orang lain yang terdapat dalam masing masing pasal tersebut:

a. Pasal 338 KUHPidana

"Barangsiapa dengan sengaja merampas nyawa orang lain, diancam karena pembunuhan dengan pidana penjara paling lama lima belas tahun."

b. Pasal 339 KUHPidana

"Pembunuhan yang diikuti, disertai atau didahului oleh suatu perbuatan pidana, yang dilakukan dengan maksud untuk suatu persiapan atau mempermudah pelaksanaannya, atau untuk melepaskan diri sendiri maupun peserta lainnya dari pidana dlam hal tertangkap tangan, ataupun untuk memastikan penguasaan barang yang diperolehnya secara melawan hukum, diancam dengan pidana penjara seumur hidup atau selama waktu tertentu, paling lama dua puluh tahun."

c. Pasal 340 KUHPidana

"Barang siapa dengan sengaja dan dengan rencana terlebih dahulu merampas nyawa orang lain, diancam karena pembunuhan dengan rencana, dengan pidana mati atau pidana penjara seumur hidup atau selama waktu tertentu, paling lama dua puluh tahun."

d. Pasal 344 KUHPidana

"Barangsiapa merampas nyawa orang lain atas permintaan orang itu sendiri yang jelas dinyatakan dengan kesungguhan hati, diancam dengan pidana penjara paling lama dua belas tahun."

e. Pasal 345 KUHPidana

"Barangsiapa sengaja mendorong orang lain untuk bunuh diri, menolongnya dalam perbuatan itu atau memberi saran

\footnotetext{
${ }^{17}$ Franz Magnis-Suseno, Etika Dasar, Kanisius, Yogyakarta, 1987, h. 126.

${ }^{18}$ Soeroso, Pengantar Ilmu Hukum, Cetakan I, Bumi Aksara, Surabaya, 2019, h.
} 
kepadanya untuk itu, diancam dengan pidana penjara paling lama empat tahun kalau orang itu jadi bunuh diri."

f. Pasal 359 KUHPidana

"Barangsiapa karena kesalahannya(kealpaannya) menyebabkan orang lain mati, diancam dengan pidana penjara paling lama lima tahun atau pidana kurungan paling lama satu tahun."

g. Pasal 361 KUHPidana

"Jika kejahatan yang diterangkan dalam bab ini dilakukan dengan menjalankan suatu jabatan atau pencarian, maka pidana ditambahkan dengan sepertiga dan yang bersalah dapat dicabut haknya untuk menjalankan pencarian dalam mana dilakukan kejahatan dan hakim dapat memerintahkan supaya putusannya diumumkan.

Jika mengacu pada pasal pasal diatas Penghentian Terapi Bantuan Hidup (Withdrawing of life support) memang mempunyai konsekuensi medis kemungkinan pasien meninggal. Namun apakah tindakan Penghentian Terapi Bantuan Hidup tersebut dapat tergolong kedalam tindakan kejahatan terhadap nyawa? Kita perlu merinci unsur unsur tindakan kejahatan terhadap nyawa, yaitu:

\section{Unsur subyektifitas dengan sengaja}

Dengan sengaja artinya bahwa perbuatan itu harus disengaja dan kesengajaan itu harus timbul seketika itu juga, karena sengaja (opzet/dolus) yang dimaksud dalam Pasal 338 KUHPidana adalah perbuatan sengaja yang telah terbentuk tanpa direncanakan terlebih dahulu, sedangkan yang dimaksud sengaja dalam Pasal 340 KUHP adalah suatu perbuatan yang disengaja untuk menghilangkan nyawa orang lain yang terbentuk dengan direncanakan terlebih dahulu. Secara umum terdapat tiga bentuk sengaja, yakni:

a) sengaja sebagai niat,

b) sengaja insaf akan kepastian, dan

c) sengaja insaf akan kemungkinan

Unsur sengaja sebagai niat, yaitu hilangnya nyawa seseorang harus dikehendaki. Kondisi hilangnya nyawa harus menjadi tujuan. Suatu perbuatan dilakukan dengan maksud atau tujuan atau niat untuk menghilangkan jiwa seseorang secara terencana. Hilangnya nyawa seseorang tanpa disertai dengan sengaja atau tanpa maksud niat utama sebelumnya, tidak dapat dinyatakan sebagai pembunuhan, jadi dengan sengaja berarti mempunyai maksud atau niat atau tujuan untuk menghilangkan jiwa seseorang. ${ }^{19}$

Sebagian besar tindak pidana mempunyai unsur kesengajaan atau opzet, bukan culpa. Hal ini dikarenakan, yang pantas mendapat hukuman pidana itu adalah orang yang melakukan sesuatu dengan sengaja. Dalam kesengajaan yang bersifat tujuan, dapat dikatakan bahwa si pelaku benar-benar menghendaki mencapai akibat yang menjadi pokok alasan diadakan ancaman pidana

Menurut Prodjodikoro Pengertian sengaja insaf akan kepastian, sebagai berikut: "Kesengajaan semacam ini ada apabila si pelaku, dengan perbuatannya itu bertujuan untuk mencapai akibat yang akan menjadi dasar dari tindak pidana, kecuali ia tahu benar, bahwa akibat itu mengikuti perbuatan itu". ${ }^{20}$ Kesengajaan semacam ini ada apabila si pelaku dengan perbuatannya tidak bertujuan untuk mencapai akibat yang menjadi dasar, tapi ia tahu benar bahwa akibat itu pasti akan mengikuti perbuatan itu

Selanjutnya Lamintang mengemukakan sengaja insaf akan kemungkinan, adalah pelaku yang bersangkutan pada waktu melakukan perbuatan menyadari adanya kemungkinan akan timbul suatu akibat yang dilarang oleh undang-undang. Pelaku menyadari kemungkinan akan timbul suatu akibat lain dari pada akibat yang memang ia kehendaki. ${ }^{21}$ kesengajaan ini dianggap terjadi apabila dalam gagasan si pelaku hanya ada bayangan kemungkinan belaka, bahwa akan terjadi akibat yang bersangkutan tanpa dituju. Maka harus ditinjau seandainya ada bayangan kepastian, tidak hanya kemungkinan, maka apakah perbuatan itu tetap akan dilakukan oleh si pelaku. Kalau hal ini terjadi, maka dapat dikatakan bahwa kalau perlu akibat yang terang tidak dikehendaki dan hanya mungkin akan terjadi itu, akan dipikul pertanggungjawabannya oleh si pelaku jika akibatnya tetap terjadi.

2. Unsur obyektif perbuatan menghilangkan nyawa.

Unsur perbuatan menghilangkan nyawa ini juga diliputi oleh kehendak, artinya pelaku harus menghendaki dengan sengaja, melakukan tindakan menghilangkan nyawa tersebut, dan ia pun harus mengetahui, bahwa tindakannya itu bertujuan menghilangkan nyawa orang lain. Dalam perbuatan menghilangkan nyawa orang lain terdapat unsur unsur tindak pidana pembunuhan sebagai berikut:

a. Adanya suatu perbuatan yang menyebabkan matinya orang, hubungan ini ada dalam alam kenyataan;

b. Adanya kesengajaan yang tertuju kepada terlaksananya kematian orang itu, hubungan ini ada dalam alam batin;

c. Kesengajaan merampas nyawa orang itu dilakukan segera setelah timbulnya niat (untuk membunuh);

Dalam konteks perbuatan Penghentian Terapi Bantuan Hidup jika dianalisa dalam unsur unsur kejahatan terhadap nyawa maka unsur obyektifitas yang memuat tujuan dari perbuatan tersebut sangatlah berbeda. Tujuan utama dari Penghentian Terapi

\footnotetext{
${ }^{19}$ Zainal Abidin Farid, Hukum Pidana, Cetakan I, Sinar Grafika, Makassar, 2007, h. 262.

${ }^{20}$ Wiryono Prodjodikoro, Asas Asas Hukum Pidana di Indonesia, Edisi 6, Refika Aditama 2014, h.63.

${ }^{21}$ Lamintang, Dasar Dasar Hukum Pidana Indonesia, Edisi 2, Sinar Grafika, Jakarta, 2012, h.18.
} 
Bantuan Hidup adalah menghentikan terapi yang dianggap tidak berguna atau sia sia pada pasien dengan penyakit yang tidak dapat disembuhkan, bukan bertujuan untuk menghilangkan nyawa. Terlebih tindakan penghentian diatur dengan jelas dalam Permenkes Penentuan Kematian dan Pemanfaatan Organ Donor yaitu hanya pada tindakan extraordinary yang bersifat penyembuhan (cure). Sedangkan tindakan yang bersifat perawatan (care) tetap diberikan kepada pasien dan membiarkan proses akhir kehidupan berjalan alamiah. Sangat berbeda tujuannya dengan pembunuhan.

Bahwa suatu perbuatan dianggap telah melanggar hukum dan dapat dikenakan sanksi pidana, harus dipenuhi dua unsur, yaitu adanya unsur actus reus (physical element) dan unsur mens rea (mental element). Unsur actus reus adalah esensi dari kejahatan itu sendiri atau perbuatan yang dilakukan, sedangkan unsur mens rea adalah sikap batin pelaku pada saat melakukan perbuatan. Dalam ilmu hukum pidana, perbuatan lahiriah itu dikenal sebagai actus reus, sedangkan kondisi jiwa atau sikap kalbu dari pelaku perbuatan itu disebut mens rea. Jadi actus reus adalah merupakan elemen luar (external element), sedangkan mens rea adalah unsur kesalahan (fault element). ${ }^{22}$ Kesalahan dari suatu perbuatan dalam hukum Pidana dapat dinilai dari 3 unsur yaitu:

1. Keadaan jiwa pelaku

Mengacu pada BAB III Pasal 44 ayat (1) KUHPidana tentang Hal Hal Yang Menghapuskan, Mengurangi atau Memberatkan Pidana. Keadaan cacat jiwa dalam pertumbuhannya, terganggu karena penyakit (bisu, tuli, buta sejak lahir) tidak dapat dipidana.

2. Ada kesengajaan (dolus) atau kelalaian (culpa).

- Kesengajaan mempunyai batasan sebagai kehendak untuk melakukan perbuatan yang dilarang, atau tidak melakukan perbuatan yang diperintahkan oleh Undang-Undang.

- Sedangkan kelalaian mempunyai batasan sebagai tidak berbuat hati-hati sehingga perbuatannya menimbulkan akibat yang seharusnya dapat diduga. Ukuran hati hati merujuk pada bagaimana masyarakat bertindak semestinya seperti standart profesi, SPO atau praktik sejawat lainnya yang sesuai.

3. Tidak alasan pembenar atau pemaaf.

- Alasan pembenar merujuk pada pembelaan terpaksa sesuai Pasal 49 ayat (1) KUHPidana, melaksanakan undang undang (pasal 50 KUHPidana) dan menjalankan perintah jabatan sesuai Pasal 51 ayat (1) KUHPidana.

- Alasan pemaaf diantaranya pembelaan terpaksa melampaui batas sesuai Pasal 49 ayat (2) KUHPidana dan menjalankan perintah jabatan yang diberikan oleh penguasa yang tidak berwenang tetapi seakan akan berwenang sesuai Pasal 51 ayat (2) KUHPidana.

Permenkes Penentuan Kematian dan Pemanfaatan Organ Donor telah memberikan kepastian hukum bagi Dokter sebagai pelaku Penghentian Terapi Bantuan Hidup. Permenkes ini memberikan acuan apakah terpenuhi unsur kesalahan bagi Dokter yang merujuk pada standart prosedur operasional. Selama tindakan Penghentian Terapi Bantuan Hidup memenuhi standart (syarat kapan dan bagaimana) maka unsur kelalaian tidak terpenuhi.

Dengan demikian tindakan dokter sebagai pelaku Penghentian Terapi Bantuan Hidup di Indonesia tidak dapat di golongkan sebagai kejahatan pidana terhadap nyawa. Secara perbuatan lahiriah memang tindakan tersebut dapat berakibat hilangnya nyawa seseorang. Namun sikap batin (mens rea) dalam tindakan Penghentian Terapi Bantuan Hidup sangat berbeda jauh dengan pembunuhan. Penghentian Terapi Bantuan Hidup dilakukan dengan merujuk pada kepentingan dan kebaikan pasien serta keluarga berlandaskan keilmuan medis. Sedangkan kejahatan merampas nyawa mempunyai kepentingan tujuan pada pribadi pelaku bukan pada korban.Terlebih tindakan ini telah mendapatkan payung hukum dengan diterbitkannya Permenkes tentang Penentuan Kematian dan Pemanfaatan Organ Donor. Dalam Permenkes tentang Penentuan Kematian dan Pemanfaatan Organ Donor tersebut diatur secara rinci jenis bantuan hidup mana yang boleh dihentikan dan mana yang tidak boleh dihentikan, sehingga menjadi pembeda dengan kejahatan merampas nyawa orang lain seperti yang diatur dalam Pasal 344 KUHPidana.

Ajaran pertanggungjawaban pidana pengganti (doctrine of vicarious liability), prinsip pendelegasian (the delegation principle) dan prinsip perbuatan buruh adalah perbuatan majikan (the servent's act is the master's act in law) merupakan prinsip prinsip pembenar bahwa korporasi dalam hal ini Rumah Sakit ikut bertanggungjawab terhadap perbutan hukum dokter. ${ }^{23}$ Begitupun dalam Teori pertanggungjawaban pejabat (fautes de services) menurut Kranenburg dan Vegtig, menyatakan bahwa kerugian terhadap pihak ketiga dibebankan pada instansi dari pejabat yang bersangkutan. Menurut teori ini tanggung jawab dibebankan juga kepada jabatan. Sehingga mengenai tanggung jawab hukum dokter dalam Penghentian Tindakan Medis juga menyangkut tanggung jawab dari pihak rumah sakit. Selayaknya dokter dan Rumah Sakit ikut mengkaji dan menyiapkan regulasi terkait tanggung jawab hukum terhadap tindakan Penghentian Terapi Bantuan Hidup.

\section{E. Pertanggungjawaban Hukum Perdata bagi Dokter Sebagai Pelaku Penghentian Terapi Bantuan Hidup.}

Perbuatan hukum baru terjadi apabila ada "pernyataan kehendak". Untuk adanya pernyataan kehendak diperlukan adanya dua unsur yaitu kehendak akan sesuatu dan pernyataannya. Subyek hukum harus memenuhi dua unsur tersebut agar muncul perbuatan hukum. Dalam Penghentian Terapi Bantuan Hidup, hendaklah dipahami benar mulai dari subyek hukum, perbuatan hukum dan akibat hukumnya sehingga tidak menimbulkan kerugian secara hukum bagi dokter sebagai pelaku tindakan tersebut. Dokter harus memahami aturan-aturan mana yang diperbolehkan secara hukum dan mana yang tidak oleh.

\footnotetext{
22 Zainal Abidin Farid, Op. Cit, 35

${ }^{23}$ Andriano, Mereview Konsep Pertanggungjawaban Pidana Korporasi, Scopindo Media Pustaka, Surabaya, 2019, h. 33.
} 
Dalam menjalankan profesinya, dokter senantiasa mengutamakan keselamatan pasien (agrotisalus lex suprema) sehingga tanggung jawab dokter selalu berorientasi pada apa yang terbaik untuk pasien ditinjau dari keilmuan kedokteran. ${ }^{24}$ Batasanbatasan yang harus diperhatikan dan ditaati oleh seorang dokter dalam memahami tanggung jawabnya saat pelayanan medis atau praktik kedokteran merujuk pada Kode Etik Kedokteran (KODEKI) sebagai kesepakatan bersama oleh ikatan profesinya dan aturan hukum negara yang berbentuk Undang-Undang. Peraturan perundangundangan yang jamak menjadi pedoman dan acuan seorang dokter dalam menjalankan profesinya adalah Undang-Undang No. 29 Tahun 2004 tentang Praktik Kedokteran, UndangUndang No. 36 Tahun 2009 tentang Kesehatan, Undang-Undang No. 44 Tahun 2009 tentang Rumah Sakit dan Undang Undang Nomor 36 tahun 2014 tentang Tenaga Kesehatan

Ditinjau dari Hukum Perdata, Undang Undang Nomor 36 tahun 2009 Pasal 58 ayat (1) menyebutkan; "Setiap orang berhak menuntut ganti rugi terhadap seseorang, tenaga Kesehatan dan atau penyelenggara kesehatan yang menimbulkan kerugian akibat kesalahan atau kelalaian dalam pelayanan Kesehatan yang diterimanya." Begitu juga termuat dalam Undang Undang Nomor 36 tahun 2014 tentang Tenaga Kesehatan Pasal 77 yang berbunyi; "Setiap penerima pelayanan Kesehatan yang dirugikan akibat kesalahan atau kelalaian Tenaga Kesehatan dapat meminta ganti rugi sesuai dengan peraturan perundang-undangan.” Kesalahan yang dimaksud dalam Hukum Perdata mempunyai dua bentuk yaitu:

1. Wanprestasi.

Sederhananya, wanprestasi itu adalah ingkar janji atau tidak menepati janji, atau tidak melaksanakan prestasi yang telah diperjanjikan. Wanprestasi adalah suatu sikap dimana seseorang tidak memenuhi atau lalai melaksanakan kewajiban sebagaimana yang telah ditentukan dalam perjanjian yang dibuat oleh para pihak. Keadaan wanprestasi terjadi jika salah satu tidak memenuhi janjinya atau tidak memenuhi sebagaimana mestinya dan kesemuanya itu dapat dipersalahkan kepadanya. ${ }^{25}$ Dalam Pasal 1243

Kitab Undang-Undang Hukum Perdata (KUHPerdata) keadaan wanprestasi diatur; "Penggantian biaya, kerugian dan bunga karena tak dipenuhinya suatu perikatan mulai diwajibkan, bila debitur, walaupun telah dinyatakan lalai, tetap lalai untuk memenuhi perikatan itu, atau jika sesuatu yang harus diberikan atau dilakukannya hanya dapat diberikan atau dilakukannya dalam waktu yang melampaui waktu yang telah ditentukan ". Bentuk bentuk wanprestasi bisa berupa:

- Tidak melaksanakan prestasi sama sekali

- Melaksanakan tapi tidak sesuai seperti yang dijanjikan

- Melaksanakan tetapi terlambat

- Melakukan sesuatu yang menurut perjanjian tidak boleh dilakukan.

Dalam Pasal 1244 KUHPerdata diatur; ’Debitur harus dihukum untuk mengganti biaya, kerugian dan bunga. bila ia tak dapat membuktikan bahwa tidak dilaksanakannya perikatan itu atau tidak tepatnya waktu dalam melaksanakan perikatan itu disebabkan oleh sesuatu hal yang tak terduga, yang tak dapat dipertanggungkan kepadanya. walaupun tidak ada itikad buruk kepadanya."

2. Perbuatan Melawan Hukum (onrechmatige daad)

Mengacu pada Pasal 1365 Burgerlijk Wetboek yang berbunyi; “Tiap perbuatan melanggar hukum yang membawa kerugian kepada seorang lain, mewajib kan orang yang karena salahnya menerbitkan kerugian itu, mengganti kerugian tersebut." Dari bunyi pasal tersebut, maka dapat ditarik unsur-unsur Perbuatan Melawan Hukum sebagai berikut:

a. ada perbuatan melawan hukum;

b. ada kesalahan

c. ada hubungan sebab akibat antara kerugian dan perbuatan;

d. ada kerugian.

Perbuatan melawan hukum berarti adanya perbuatan atau tindakan dari pelaku yang melanggar melawan hukum. Pengertian melawan hukum tidak hanya terbatas pada undang-undang (hukum tertulis saja) tapi juga hukum yang tidak tertulis, sebagai berikut;

- Melanggar Undang-Undang, artinya perbuatan yang dilakukan jelas-jelas melanggar undang-undang.

- Melanggar hak subjektif orang lain, artinya jika perbuatan yang dilakukan telah melanggar hak-hak orang lain yang dijamin oleh hukum (termasuk pada hak yang bersifat pribadi, kebebasan, hak kebendaan, kehormatan, nama baik ataupun hak perorangan lainnya).

- Bertentangan dengan kewajiban hukum si pelaku, artinya kewajiban hukum baik yang tertulis maupun yang tidak tertulis, termasuk hukum publik.

- Bertentangan dengan kesusilaan, yaitu kaidah moral (Pasal 1335, Pasal 1337 KUHPerdata)

- Bertentangan dengan sikap kehati-hatian yang sepatutnya dalam masyarakat. Kriteria ini bersumber pada hukum tak tertulis (bersifat relatif). Yaitu perbuatan yang dilakukan bertentangan dengan sikap yang baik atau kepatutan dalam masyarakat untuk memperhatikan kepentingan orang lain.

\footnotetext{
${ }^{24}$ Syafrudin, Arif Rohman, Model Perlindungan dan Pemenuhan Hak Pasien terhadap Pelaksanaan Informed Consent di Indonesia, Jurnal Mimbar Hukum, Volume 31 Nomor 2, Juni 2019, h, 226.

${ }^{25}$ Abdul Saliman, Esensi Hukum Bisnis Indonesia: Teori dan Contoh Kasus, Kencana Press, Jakarta, 2004, h. 15.
} 
Kesalahan dalam Perdata bisa karena kesengajaan atau karena kealpaan. Kesengajaan maksudnya ada kesadaran yang oleh orang normal pasti tahu konsekuensi dari perbuatannya itu akan merugikan orang lain. Sedang, kealpaan berarti ada perbuatan mengabaikan sesuatu yang mestinya dilakukan, atau tidak berhati-hati atau teliti sehingga menimbulkan kerugian bagi orang lain. ${ }^{26}$ Namun demikian adakalanya suatu keadaan tertentu dapat meniadakan unsur kesalahan, misalnya dalam hal keadaan memaksa (overmacht) atau si pelaku tidak sehat pikirannya (gila).

Unsur berikutnya hubungan kausalitas yaitu hubungan sebab akibat antara perbuatan yang dilakukan dengan akibat kerugian yang muncul. Misalnya, kerugian yang terjadi disebabkan perbuatan si pelaku atau dengan kata lain, kerugian tidak akan terjadi jika pelaku tidak melakukan perbuatan melawan hukum tersebut. Kerugian di sini dibagi jadi 2 (dua) yaitu materiil dan imateriil. Kerugian materiil adalah kerugian yang nyata nyata diderita oleh pemohon. Sedangkan kerugian imateriil adalah kerugian yang muncul atas manfaat yang kemungkinan diterima oleh pemohon di kemudian hari.

Tuntutan Perbuatan Melanggar Hukum ada dalam beberapa bentuk diantaranya;

1. Memberikan ganti rugi (materiil dan immaterial).

2. Melakukan suatu perbuatan.

3. Tidak melakukan suatu perbuatan.

Kriteria Melanggar Hukum harus memenuhi pelanggaran terhadap hak orang lain, pelanggaran terhadap kewajiban hukum pelaku, melanggar kepatutan dan kesusilaan dan melanggar tingkah laku sebagai warga negara yang baik. Poin terakhir, tingkah laku yang baik bagi dokter diukur dari Standart profesi, standar prosedur operasional, Kode Etik Profesi atau kebiasaan tingkah laku sejawat profesi.

Dari uraian diatas, pembahasan Persetujuan Tindakan menjadi hal yang sangat penting bagi pertanggungjawaban perdata dokter dalam tindakan Penghentian Terapi Bantuan Hidup. Persetujuan Tindakan menjadi bukti bentuk kesepakatan dalam perjanjian sebagai acuan memenuhi unsur wanprestasi atau tidak. Penghentian Terapi Bantuan Hidup wajib mendapatkan persetujuan pasien dan atau keluarga pasien dengan pertimbangan menurut keilmuan kedokteran dan secara akal sehat sudah tidak harapan lagi bagi pasien untuk sembuh, yang disebabkan oleh kecelakaan atau penyakit yang pasien tersebut mendekati tahap akhir kehidupan. Berdasarkan isi Pasal 45 Undang Undang Praktek Kedokteran, pasal 5, pasal 6, pasal 14, pasal 16 dan pasal 17

Peraturan Menteri Kesehatan tentang Persetujuan Tindakan Kedokteran diatas, maka wajib hukumnya persetujuan pasien atau keluarga dilakukan secara tertulis sebelum dilakukan tindakan Penghentian Terapi Bantuan Hidup. Persetujuan tersebut dapat dilakukan setelah memperoleh penjelasan dari tim dokter yang bersangkutan. Persetujuan pasien atau keluarga tidak serta merta menghapus tanggung gugat hukum dokter apabila ditemukan unsur kelalaian dokter yang menimbulkan kerugian pasien. Oleh karena itu, dokter haruslah mengetahui sedetail mungkin syarat apa dan bagaimana Penghentian Terapi Bantuan Hidup dapat dilakukan merujuk pada Peraturan Menteri Kesehatan tentang Penentuan Kematian dan Pemanfaatan Organ Donor.

Ada atau tidaknya Perbuatan Melanggar Hukum dalam Tindakan Penghentian Terapi Bantuan Hidup oleh dokter, sangat tergantung terpenuhi atau tidaknya unsur unsur Perbuatan Melanggar Hukum. Karena itu kejelasan regulasi tentang tindakan Penghentian Terapi Bantuan Hidup menjadi sangat penting sebagai tolak ukur ada tidaknya penyimpangan. Dalam Pasal 14 Angka (2) Peraturan Menteri Kesehatan tentang Penentuan Kematian dan Pemanfaatan Organ Donor disebutkan; "Kebijakan mengenai kriteria keadaan pasienyang terminal state dan Tindakan kedokteran yang sudah sia sia (futile) ditetapkan oleh Direktur atau Kepala Rumah Sakit.” Artinya tim dokter bersama sama dengan Rumah Sakit juga perlu mempersiapkan regulasi tentang kriteria-kriteria terukur kapan Penghentian Terapi Bantuan Hidup dapat dilakukan. Hal itu dikarenakan dokter merupakan tenaga kesehatan yang ditanggung kerugiaannya oleh pihak Rumah Sakit di mana dokter tersebut bekerja atas kelalaian yang telah dilakukannya. Sebagaimana tercantum di dalam Pasal 46 Undang-Undang Rumah Sakit yang berbunyi, bahwa: "Rumah sakit bertanggung jawab secara hukum terhadap semua kerugian yang ditimbulkan atas kelalaiam yang ditimbulkan oleh tenaga kesehatan di Rumah Sakit."

Jika syarat Penghentian Terapi Bantuan Hidup terpenuhi, maka pelaksanaanya pun masih diatur secara ketat. Permenkes Penentuan Kematian dan Pemanfaatan Organ Donor merinci jenis bantuan hidup yang bisa dihentikan yaitu terapi bersifat luar biasa (extra-ordinary) seperti diatur dalam Pasal 14 angka (5). Permenkes ini mengatur jelas batas batas tindakan yang boleh dan mana yang tidak. Prinsip tanggung jawab berdasarkan unsur kesalahan (fault liability atau liability based on fault), yaitu prinsip yang cukup umum berlaku dalam hukum perdata. Dalam Kitab Undang-Undang Hukum Perdata, khususnya pasal 1365, 1366, dan 1367, prinsip ini dipegang secara teguh. Prinsip ini menyatakan, tanggung jawab hukum dokter dalam seseorang baru dapat dimintakan pertanggungjawabannya secara hukum jika ada unsur kesalahan yang dilakukannya.

Jika Penghentian Terapi Bantuan Hidup ini dilaksanakan atas inisiatif dari pihak dokter yang merawat pasien terminal, namun pihak keluarga tidak menyetujui untuk dilakukan penghentian tindakan medis tersebut, maka berdasarkan hal itu dapat merujuk pada teori pertanggungjawaban hukum, yaitu teori fautes personalles. Teori fautes personalles menyatakan bahwa kerugian terhadap pihak ketiga dibebankan kepada pejabat yang karena tindakannya itu telah menimbulkan kerugian. Dalam teori ini beban tanggung jawab ditujukan pada manusia selaku pribadi. Sehingga kemungkinan apabila ada pelaporan dari pihak keluarga kepada kepolisian, maka hal itu sudah termasuk ke dalam ranah perdata bahkan pidana yaitu mengenai euthanasia dalam hal ini adalah euthanasia aktif. Pihak rumah sakit di mana tempat bekerja dokter yang bersangkutan tidak dapat dimintakan pertanggungjawabannya.

\footnotetext{
${ }^{26}$ Moegni Djojodirdjo: Perbuatan Melawan Hukum, Pradnya Paramita, Jakarta, 1982.
} 
Website : http://yustisia.unmermadiun.ac.id/index.php/yustisia

Dengan demikian pertanggungjawaban perdata bagi Dokter sebagai pelaku Penghentuan Terapi Bantuan Hidup baru dapat diminta jika ada unsur kesalahan perdata yaitu adanya wanprestasi atau perbuatan melanggar hukum (onrechtmatige daad). Unsur kesalahan, kerugian dan hubungan kausa antara keduanya harus terpenuhi. Pertanggungjawaban perdata muncul apabila ada pelanggaran terhadap hak orang lain, pelanggaran terhadap kewajiban hukum pelaku, melanggar kepatutan dan kesusilaan dan melanggar tingkah laku sebagai warga negara yang baik. Poin terakhir, tingkah laku yang baik bagi dokter diukur dari Standart profesi, standar prosedur operasional, Kode Etik Profesi atau kebiasaan tingkah laku sejawat profesi.

\section{KESIMPULAN DAN SARAN}

\section{A. Kesimpulan}

1. Norma hukum Penghentian Terapi Bantuan Hidup di Indonesia telah diatur dalam Permenkes tentang Penentuan Kematian dan Pemanfaatan Organ Donor. Penghentian Terapi Bantuan Hidup dapat dilakukan pada pasien kondisi terminal (terminal state) dan jika segala upaya medis yang diberikan sudah dinilai sia sia (futile). Kebijakan mengenai kriteria keadaan pasien terminal dan tindakan kedokteran yang sia sia ditetapkan oleh Direktur atau Kepala Rumah Sakit. Ditinjau dari asas kemanfaatan tentunya akan lebih baik menghentikan upaya yang sudah tidak berguna dengan memberikan kebebasan pada pasien menjalani akhir kehidupannya namun tetap memberikan perawatan dasar. Penghentian Terapi Bantuan Hidup ini sejalan dengan prinsip Perawatan Paliatif karena justru dengan meneruskan upaya extraordinary yang sia sia akan bertolak belakang dengan prinsip Perawatan Paliatif yaitu tidak bertujuan mempercepat atau menunda kematian pasien.

2. Tanggung jawab hukum Dokter sebagai pelaku Penghentian Terapi Bantuan Hidup di Indonesia adalah menjalan sesuai kriteria yang diatur dalam Perrmenkes tentang Penentuan Kematian dan Pemanfaatan Organ Donor. Tindakan Penghentian Terapi Bantuan Hidup ini tidak dapat di golongkan sebagai kejahatan pidana terhadap nyawa (Pasal 344 KUHPidana) meskipun secara perbuatan lahiriah (actus reus) tindakan tersebut dapat berakibat hilangnya nyawa seseorang. Namun sikap batin (mens rea) dalam tindakan Penghentian Terapi Bantuan Hidup sangat berbeda dengan pembunuhan. Pertanggungjawaban perdata bagi Dokter sebagai pelaku Penghentuan Terapi Bantuan Hidup baru dapat diminta jika ada unsur kesalahan perdata yaitu adanya wanprestasi atau perbuatan melanggar hukum (onrechtmatige daad). Pertanggungjawaban perdata muncul apabila ada pelanggaran hak orang lain, pelanggaran kewajiban hukum pelaku, melanggar kepatutan kesusilaan dan melanggar tingkah laku sebagai warga negara yang baik yang diukur dari Standart profesi, standar prosedur operasional, Kode Etik Profesi atau kebiasaan tingkah laku sejawat profesi.

\section{B. Saran}

1. Tindakan Penghentian Terapi Bantuan Hidup seringkali dipandang mirip dengan merampas nyawa orang lain sehingga perlu kiranya dirumuskan peraturan setingkat Undang Undang yang mengatur lebih khusus tentang isu pengakhiran kehidupan khususnya di bidang medis. Hal ini dalam rangka memberikan Kepastian Hukum bagi pasien dan keluarganya, khusunya dokter yang merawat pasien.

2. Setiap Dokter dan Rumah Sakit sebagai pemberi layanan kesehatan wajib menetapkan kebijakan terkait kriteria keadaan pasien terminal state dan kriteria tndakan kedokteran yang sudah sia sia (futile) sebagai rambu rambu dan dasar hukum pengambilan keputusan medis dalam Tindakan Penghentian Terapi Bantuan Hidup. Regulasi tersebut disesuaikan dengan sumber daya yang dimiliki masing masing Rumah Sakit. Tanpa adanya regulasi ini maka Dokter dan Rumah Sakit beresiko dimintai pertangungjawaban pidana dan perdata.

\section{VI.DAFTAR PUSTAKA}

\section{A. Buku}

Abdul Saliman, Esensi Hukum Bisnis Indonesia: Teori dan Contoh Kasus, Kencana Press, Jakarta, 2004. Andriano, Mereview Konsep Pertanggungjawaban Pidana Korporasi, Scopindo Media Pustaka, Surabaya, 2019

Franz Magnis-Suseno, Etika Dasar, Kanisius Press, Yogyakarta, 1987.

Gunawandi, Hukum Medik (Medical Law), Penerbit Buku Kesehatan Fakultas Ilmu Kedokteran Universitas Indonesia, Jakarta, 2007.

Hadikusumo, Hilman, Pengantar Ilmu Hukum Adat Indonesia, CV Mandar Maju, Bandung, 2003

Kartono M, Tehnologi Kedokteran dan Tantangannya Terhadap Bioetika, PT. Gramedia Pustaka Utama, Jakarta, 1992. Lamintang, Dasar Dasar Hukum Pidana Indonesia, Edisi 2, Sinar Grafika, Jakarta, 2012.

Moegni Djojodirdjo, Perbuatan Melawan Hukum, Pradnya Paramita, Jakarta, 1982

O’Rourke K.A, Primer for Health Care Ethics. Essays for Pluralistic Society. Washington DC: Georgetown University Press; 2000

Peter Mahmud Marzuki, Penelitian Hukum, Kencana Prenada Media Group, cetakan II, Jakarta, 2005

Zainudin Ali, Metode Penelitian Hukum, Sinar Grafika. Jakarta 2015 hal 25-26

Schedule D, Withholding and Withdrawing Life Sustaining Treatment, Standards of Practice of Medicine, CPSM By Law, 2008.

Tim Mulgan, Understanding Utilitarianism, Acumen Press, Stocksfield, 2007

Wiryono Prodjodikoro, Asas Asas Hukum Pidana di Indonesia, Edisi 6, Refika Aditama, 2014. Zainal Abidin Farid, Hukum Pidana, Cetakan I, Sinar Grafika, Makassar, 2007. 
Website : http://yustisia.unmermadiun.ac.id/index.php/yustisia

\section{B. Jurnal}

Bandraouk Dowener, Withholding and Withdrawing of Life-Sustaining Treatment: The Canadian Critical Care Society Position Paper, 2017

Hamzah Satri, Edward Faisal, Rudi Putranto, Advanced Directives Pada Pasien Perawatan Paliatif, Jurnal Penyakit Dalam Indonesia, Volume 7, Nomor 2, Juni 2020

Okorie, Ndukaku, How Impartialist is the Utilitarian Principle of Utility?, International Journal of Humanities and Social Science, Volume 10, Number. 10, 2020

Chunmei Lyu, Li Zhang, Who Decides in Withdrawal of Treatment in a Critical Care Setting?A Case Study on Ethical Dilemma, International Journal of Nursing Sciences, Volume 5, 2018.

Liliana De Lima, International Association for Hospice and Palliative Care Position Statement: Eutanasia and Physician- Assisted Suicide, Journal of Palliative Medicine, Volume 20, Number 1, 2017.

Radhakrishnan K, Van Scoy, Jillapalli, Community Based Game Intervention to Improve South Asian Indian American's Engegement With Advanced Care Planning, Ethn Heal, 2017.

Richard A. Muller, Keith Phoenix, A Dilemma for the Legal and Medical Professions, Euthanasia and the Defective Newborn, Aspen Publication, London, 1980

Syafrudin, Arif Rohman, Model Perlindungan dan Pemenuhan Hak Pasien terhadap Pelaksanaan Informed Consent di Indonesia, Jurnal Mimbar Hukum, Volume 31 Nomor 2, Juni 2019.

\section{Peraturan Perundang-undangan}

Undang-Undang Republik Indonesia Nomor 29 Tahun 2004 Tentang Praktik Kedokteran. Lembaran Negara Republik Indonesia Tahun 2004 Nomor 116. Tambahan Lembaran Negara Republik Indonesia Nomor 4431.

Undang-Undang Republik Indonesia Nomor 36 Tahun 2009 Tentang Kesehatan. Lembaran Negara Republik Indonesia Tahun 2009 Nomor 144. Tambahan Lembaran Negara Republik Indonesia Nomor 5063.

Undang-Undang Republik Indonesia Nomor 44 Tahun 2009 Tentang Rumah Sakit. Lembaran Negara Republik Indonesia Tahun 2009 Nomor 153. Tambahan Lembaran Negara Republik Indonesia Nomor 5072.

Undang-Undang Republik Indonesia Nomor 36 Tahun 2014 Tentang Tenaga Kesehatan. Lembaran Negara Republik Indonesia Tahun 2014 Nomor 298. Tambahan Lembaran Negara Republik Indonesia Nomor 5607.

Kitab Undang-Undang Hukum Perdata (KUH Perdata), Burgerlijk Wetboek Indonesia Staatsblad 1847.

Peraturan Menteri Kesehatan Nomor 37 Tahun 2014 tentang Penentuan Kematian dan Pemanfaatan Organ Donor. Keputusan Menteri Kesehatan Nomor 812 Tahun 2007 tentang Perawatan Paliatif. 